\title{
DETERMINANTS OF CUSTOMER SATISFACTION AND LOYALTY OF SHARIA COMMERCIAL BANKS IN PROVINCE EAST KALIMANTAN
}

\author{
Syahril Hasan \\ Department of Management, Institute of Economic Science, Indonesia \\ Suharno, Sri Mintarti, Yohanes Kuleh and Doddy Adhimursandi* \\ Department of Management, Faculty of Economics and Business, \\ Mulawarman University, Samarinda, Indonesia \\ * Corresponding Author
}

\begin{abstract}
Islamic banking may be an industry developed supported by Islamic law or Sharia compliance; In Indonesia, the Islamic banking industry is proliferating, including in the province of East Kalimantan. This study aims to look at the variables that affect customer satisfaction and loyalty of Islamic commercial banks in East Kalimantan at Bank Rakyat Indonesia Syariah, Bank Negara Indonesia Syariah, and Bank Syariah using 400 respondent data. This research uses Structural Equation Modeling WarpPLS, which examines measurement models and structural models using a population of 91,596 with a sample of 400 bank customers. Hypothesis testing is done by using inferential statistical test tools that will produce or draw conclusions. The independent variables include Banking Service Quality (X1), Sharia Compliance (X2), Switching Barriers (X3), Religious Influence (X4), while the endogenous variables are Satisfaction (Y1) and Loyalty (Y2). The results showed that Banking Service Quality (BSQ), Shariah Compliance (S.C.), Switching Barriers (S.B.), and Religious Effects (RE) had a significant positive effect on satisfaction. Shariah Compliance and Switching Barriers and satisfaction have a significant positive effect on loyalty. On the other hand, Banking Service Quality and Religious Influence do not significantly affect loyalty. It is suggested to management to increase customer loyalty in terms of service quality and religious influence to maintain loyalty.
\end{abstract}

Key words: Banking Service Quality, Shariah, Switching Barriers, Religion Effects, Satisfaction, Loyalty. 
Determinants of Customer Satisfaction and Loyalty of Sharia Commercial Banks in Province East Kalimantan

Cite this Article: Syahril Hasan, Suharno, Sri Mintarti, Yohanes Kuleh and Doddy Adhimursandi, Determinants of Customer Satisfaction and Loyalty of Sharia Commercial Banks in Province East Kalimantan, International Journal of Management, 11(12), 2020, pp. 1468-1479.

http://iaeme.com/Home/issue/IJM?Volume=11\&Issue=12

\section{INTRODUCTION}

Banking is one of the financial institutions that significantly influences the economy in society in a country. Banks as financial institutions are places for various parties, private companies, individuals, and government agencies to store their funds. Through credit activities and various services provided, banks serve financing needs and streamline payment mechanisms for all sectors of the economy. Over time, banks have become a necessity of life for people in a country.

In society, there are two types of banking, namely conventional banks and Islamic banks. Conventional banks are based on a general operating system based on the interest rate, while Islamic banks are based on sharia principles.

The phenomenon of shariah banking in Indonesia provides an understanding for Indonesian Muslims of economic institutions' existence from an Islamic perspective. The establishment of a sharia bank is an effort to gradually apply Islamic sharia principles to overcome the current weaknesses of the ummah in the economic and welfare fields.

The banking business is one of the businesses in the service sector, based on trust. The problem of service quality is a very determining factor in business success. The service quality of the banking business is a form of consumer assessment of the level of service received (perceived service) with the expected service level. Banks also play an essential role in the world economy. Banks are one of the service products widely used by many people with the primary objective of collecting and channeling funds.

Service quality is a reflection of consumers' evaluative perceptions of the services received at a particular time. Therefore, two main factors affect service quality, namely the expected service of consumers and the service received or perceived by consumers or the perceived results.

The main determining factor for customer satisfaction is the customer's perception of service quality. (Zeithaml et al., 2010). Developed a measurement method called Banking Service Quality specifically for the quality of banking services where the transformation of Parasuraman's (1988) SERVQUAL method is generally unspecialized and quite broad. BSQ is a specific determinant to measure service quality for the banking industry. Bahia and Nantel developed the BSQ because SERVQUAL and other service quality measures have been criticized and proven to have weaknesses. BSQ is considered better than SERVQUAL, which was developed previously by Parasuraman et al. with a memorable BSQ application domain for banking services. (Bahia \& Nantel, 2000)

The results of direct interviews with several Sharia bank customers indicated that, in general, they were less satisfied with the service when compared to conventional banks that they had previously experienced. The service quality of Islamic banks is still not capable of competing with conventional banks, including products that are not varied and services that do not match existing customer expectations. The features of Islamic banks are not suitable when compared to conventional bank products, the number of human resources (human resources) and quality, the number of branch offices, and the distribution of Automated Teller Machines (ATMs) which are still limited. Islamic bank customers view that there is confidence in the bank in terms of fulfilling Islamic laws that conventional banks do not have, and this is an 
exciting finding for researchers that being a customer of Islamic banks is a belief in the beliefs of each customer even not a little. Islamic bank customers from non-Muslim circles.

The phenomenon of customer satisfaction, when viewed from the development of Islamic banking in Indonesia, which continues to increase, the development of Islamic banking can be seen from the number of Islamic banks that continue to grow. There are 202 Islamic banks in Indonesia with three categories: Sharia Commercial Bank, Sharia Business Unit, and Sharia Rural Bank. (Financial Services Authority, 2018). Following is a Graphic of the development of Islamic banks in Indonesia

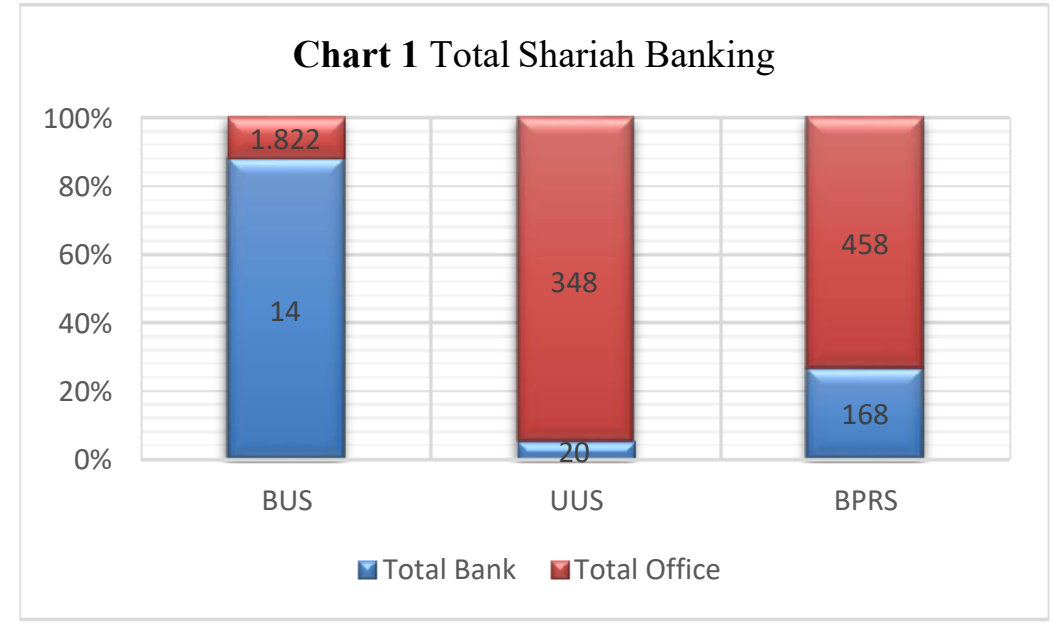

Source: (OJK, 2018)

\section{Figure 1}

Chart Total Shariah Banking above shows 14 Islamic commercial banks with several banks that exceed other business units, namely with 1,822 branch offices. This proves that the level of customer satisfaction is seen with one of these numbers. Islamic commercial banks have many customers; this can also be seen in the number of accounts from 2015 to 2018, increasing.

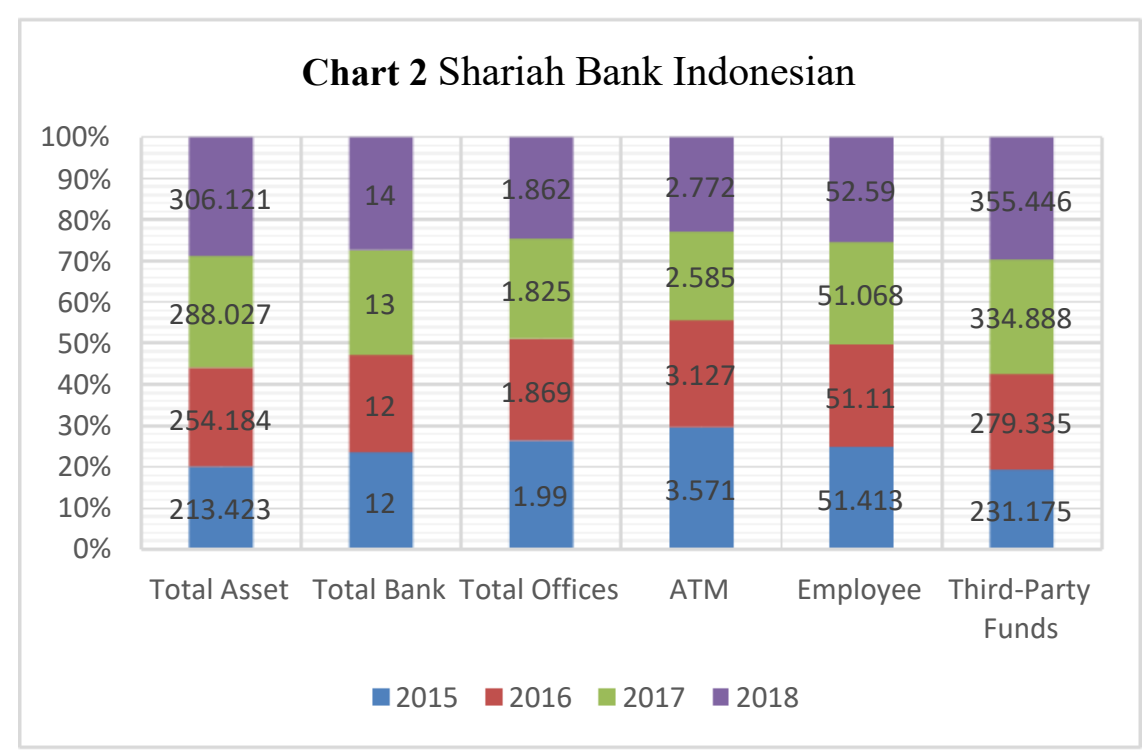

Source: (OJK, 2018)

Figure 2 


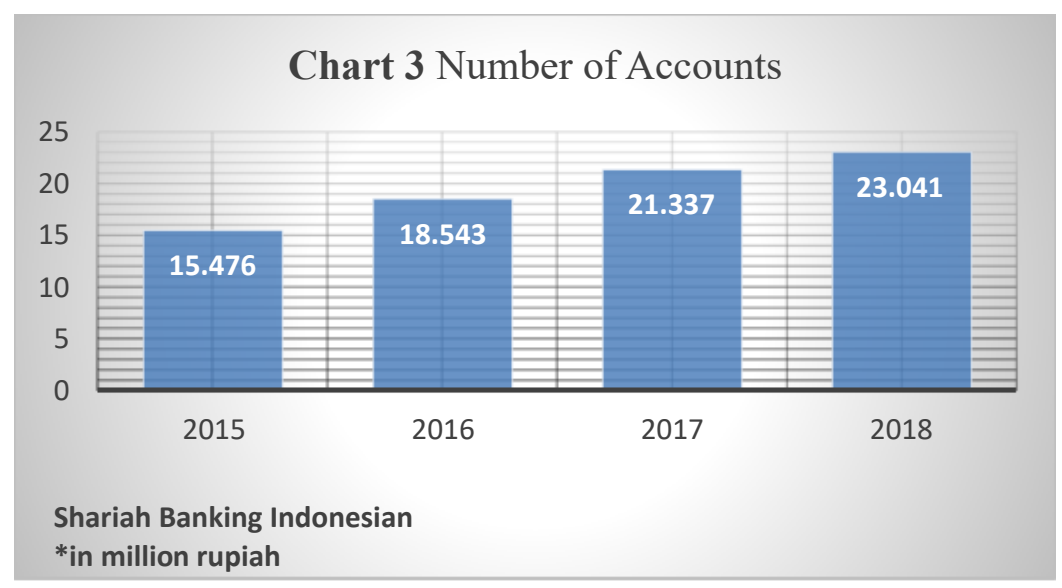

Source: SPS OJK, Sept. 2018

\section{Figure 3}

Chart Shariah Bank Indonesian and Number of Accounts above shows that Islamic banks' progress is currently increasing quantitatively, both in total assets, number of banks, third party funds, and the number of accounts. This quantitative increase is not directly proportional to the fluctuating facilities for Automated Teller Machines (ATM) and the number of employees (H.R.). The target of $6 \%$ market share in 2018 is only able to reach $5.7 \%$ at the end of 2018 , and the target until 2023 the market share of Islamic banks is expected to reach 15\%. Islamic banks' growth is still constrained by capital, human resources, and technology, while competition in the banking world is getting fierce. It can be seen from the total third-party funds at the end of 2018 amounting to Rp. 355,446,000,000 is still far from being compared with the total third party funds from conventional banking, which reached Rp. 5,363,096,000,000 in the same year.

Savings products are one of the most popular products in Islamic banking, even though the composition of bank fund sources is relatively small and the level of fluctuation in savings funds is small, unlike funds that come from stable current accounts. Savings is a type of bank product that is the most important commodity. From 2015 to 2018, there was an increase in the number of accounts at Islamic commercial banks. In 2015, 2016, 2017 and 2018 were IDR 15,476,183, IDR 18,543,305, IDR 21,337,918 and IDR 23,041,972, respectively.

East Kalimantan Province has approximately 129,066.64 kilometers and a population of approximately 3.6 million people, of which $85.57 \%$ are Muslim, which is a large market share for the Islamic economy. The performance of Islamic banks in East Kalimantan is still low. Of the total market share, banks only received $2.5 \%$ of the total performance of commercial banks; this portion is smaller than the national ratio of 5.7\%. The lack of market share cannot be ascertained with certainty, but there is strong suspicion due to the lack of Islamic banking penetration, including product socialization. People in the East Kalimantan province are considered not entirely familiar with the bank products with this sharia system. The low share of the Islamic banking market is due to the lack of education to the public. This is in line with the opinion of Islamic bank customers who are generally less satisfied with services when compared to conventional banks that they have used before. The quality of Islamic banking services is still not able to compete with conventional banks, including less varied products and services that are not in line with customer expectations. 


\section{RESEARCH QUESTION}

- Banking Service Quality (BSQ), Sharia Compliance (S.C.), Switching Barriers (S.B.), Religion Effect (RE), have a significant effect on customer satisfaction of Islamic commercial banks in East Kalimantan province?

- Banking Service Quality (BSQ), Sharia Compliance (S.C.), Switching Barriers (S.B.), Religion Effect (RE), have a significant effect on customer loyalty of Islamic commercial banks in East Kalimantan province?

\section{LITERATURE REVIEW}

Banking Service Quality developed into six dimensions, from now on named because of the quality of banking services Banking Service Quality (BSQ) which consists of Effectiveness and Assurance, Access, Price, Tangible, Service Portfolio, Reliability (Bahia \& Nantel, 2000).

SERVQUAL was service quality by applying five dimensions, namely Assurance, Reliability, Tangible, Empathy, Responsiveness. Bahia \& Nantel stated that Banking Service Quality or the standard of banking services could be a method accustomed measure service quality seen from six dimensions consisting of Effectiveness and Assurance, Access (Access), Price, and Materialization. (Tangible), Service Portfolio, Reliability, the aim of the BSQ or Banking Service Quality may be a tool to live the services that Commercial Banks have provided to their customers (Berry, 1988).

Othman \& Owen (2001) argued that shariah compliance is "The ability to satisfy with Islamic law and operate under the principles of Islamic banking and economy." Kotler (2015) states that customer satisfaction may be a feeling of enjoyment or disappointment that arises after comparing the performance (result) of the merchandise that's thought of the expected performance (or outcome). Amin \& Isa (2008), in their research "An examination of the connection between service quality perception and customer Satisfaction A SEM approach towards Malaysian Islamic banking," aims to look at the link between SERVQUAL and satisfied customers in Malaysian Islamic banking using the SEM (Structural) approach. Equation Model). The findings indicate that the quality model for the size of Islamic banking service quality must have six dimensions and satisfaction factors. The relationship between service quality and customer satisfaction is essential. During this study, the variable Service quality with six SERVQUAL dimensions significantly affects customer satisfaction.

Caruana (2002) research entitled "The effects of service quality and the mediating role of customer satisfaction." this study aims to develop a mediation model that links service quality, satisfaction, and retail banking loyalty. The results show that customer satisfaction does play a mediating role in service quality on loyalty.

Kamariah (2012) research entitled "The Impact of Service Quality on Customer Loyalty in Sudanese Banking sector" is to research the effect of service quality on customer loyalty within the Sudanese banking sector. The research model was constructed counting on the social exchange theory; the hypothesis was deducted from this model and tested on 364 customers in thirty-four banks based in Khartoum State through employing a non-probability sample. The results showed that service quality features a significant impact on customer attitudes and behavioral loyalty.

Amin et al.'s (2013) results indicate that customer satisfaction has a significant relationship with the image, the image has a significant relationship with trust, and trust has a significant relationship with customer loyalty for both customer segments. Furthermore, significant differences occur in customer satisfaction on the image, image on trust, and trust in customer loyalty between Muslim and non-Muslim customers. 
Alam et al. (2011) findings indicate that religious Muslims in Shah Alam and Bangi area consider Islam as their source of reference, and they spend moderately, as commanded by Allah in the Quran. This study confirms that religiosity acts as a fully mediating role in the relationship between relative and contextual variables and Muslim consumers' purchase behavior.

Asnawi et al.'s (2019) findings indicate that MCSQ (consisting of Islamic values, Sharia compliance, honesty, modesty, humaneness, and trustworthiness) positively influenced MCS and MCL significantly. Further, the results indicate that MCS partially mediates the influence of MCSQ on MCL.

Bloemer et al. (1998), This article investigates how image, perceived service quality, and satisfaction determine loyalty in a retail bank setting at the global construct level, as well as the level of construct dimensions. At the global level, the results of a large-scale empirical study reveal that image is indirectly related to bank loyalty via perceived quality. In turn, service quality is both directly and indirectly related to bank loyalty via satisfaction. The latter has a direct effect on bank loyalty. At the level of the dimensions underlying the constructs above, it becomes clear that reliability (a quality dimension) and position in the market (an image dimension) are relatively important drivers of retail bank loyalty.

Kau \& Loh (2006) findings showed that the complainants' level of satisfaction with service recovery was significantly affected by perceived justice. The behavioral outcomes of the complainants in terms of trust, word-of-mouth (WOM), and loyalty were also found to be affected by their satisfaction with the service recovery. T-tests confirmed that the levels of trust, WOM, and loyalty were significantly higher for those respondents who were satisfied with the service recovery compared with those who were dissatisfied. Different t-tests also indicated that respondents who were initially satisfied with the service expressed greater trust and positive WOM compared with the satisfied complainants. Finally, the study showed that dissatisfied complainants would exhibit a lower level of trust and were more likely to engage in negative word-of-mouth behavior compared with those who were dissatisfied initially but chose not to complain.

The Factor analysis technique has been employed to determine the satisfaction level of customers. The study found that the condition of banks regarding services rendered is quite dismal, and they are unable to improve the quality standards. The study also covered separately the satisfaction level of customers on innovative services provided by SBI considering 50 respondents and found that most of the services offered by SBI have remained unutilized due to the problems inherent to it. (Ahmed, 2010)

Three factors of customer loyalty have identified-loyalty to the company, response to problems, and willingness to pay. The results reveal significant differences in public and private sector banks about willingness to pay and loyalty to the company. (Hazra et al., 2013)

Shanka, (2012)The regression test results showed that offering quality service has a positive impact on overall customer satisfaction. The research proves that empathy and responsiveness play the most crucial role in customer satisfaction levels, followed by tangibility, assurance, and bank reliability. The research findings also indicate that offering high-quality service increases customer satisfaction, leading to a high level of customer commitment and loyalty.

Tabrani et al., (2018) The results of this study show that trust has a significant relationship with commitment and customer intimacy, but no significant relationship was found with customer loyalty. Commitment and customer intimacy have a significant relationship with customer loyalty. The mediation analysis reveals that commitment and customer intimacy play a mediation role in the relationship between trust and customer loyalty. 
Shaikh \& Siddiqui, (2018, pp. 830-839) Finding shows that tangibility's reliability, responsiveness, and empathy significantly affect customer satisfaction and loyalty, whereas the assurance has no significant effect on customer satisfaction and loyalty. The researcher recommends that the bank should focus on the tangibility dimension because it affects the most in the research.

Osman et al., (2016, pp. 10-19) The findings suggest that the relationship between satisfaction and profitability may reside in satisfaction's influence on trust. That satisfaction plays a crucial function within the Malaysian banking industry.

Maswadeh (2015, pp. 86 - 94)that Islamic Banks are doing well in satisfying their SMEs' customers in six dimensions of the model, namely Compliance, Assurance, Reliability, Tangibility, Empathy, and Responsiveness. However, in general, Jordanian SME respondents considered all dimensions in the CARTER model as satisfactory; those dimensions which were particularly clearly judged by the respondents as being most satisfactory are Assurance, Compliance, and Empathy, while those rated as least satisfactory are the dimensions of Reliability, Responsiveness, and Tangibility

Sunaryo, (2013, pp. 72-83)analysis showed that all relations among the variables have significant influence, both directly and indirectly, and satisfaction as an intervening variable positively impacts. Therefore, Islamic banks should give special attention to the quality of service guarantee to their customer.

\section{RESEARCH METHODOLOGY}

The type of research used is explanatory research. Explanatory research or explanatory research begins with problem identification, then continues by formulating problems, highlighting the relationships between research variables, and testing the hypotheses that have been formulated. Hypotheses are formulated based on research problems and based on previously discovered concepts. To prove this, empirical information is needed. This research uses structural equation modeling SEM (Structural Equation Modeling), which aims to test measurement models and structural models and develop new knowledge or predictions and provide direction for future researchers (Malhotra, 2006). Hypothesis testing is done using inferential statistical test tools that can generate or draw conclusions. This research is confirmative because it is conducted to test theoretical and conceptual empirical research models.

\section{DATA ANALYSIS}

Using a Likert scale, the sample used in this study represents the entire population so that the number is less than the population. Use Solvin formula with an error rate of 5\% from 91596 to 400 samples of bank customers.

\section{RESULT AND DISCUSSION}

After the WarpPLS analysis is carried out under conditions where all indicators of the construct meet the model's requirements, the depiction of the model after experiencing the model measurement test can be seen as follows: 
Determinants of Customer Satisfaction and Loyalty of Sharia Commercial Banks in Province East Kalimantan

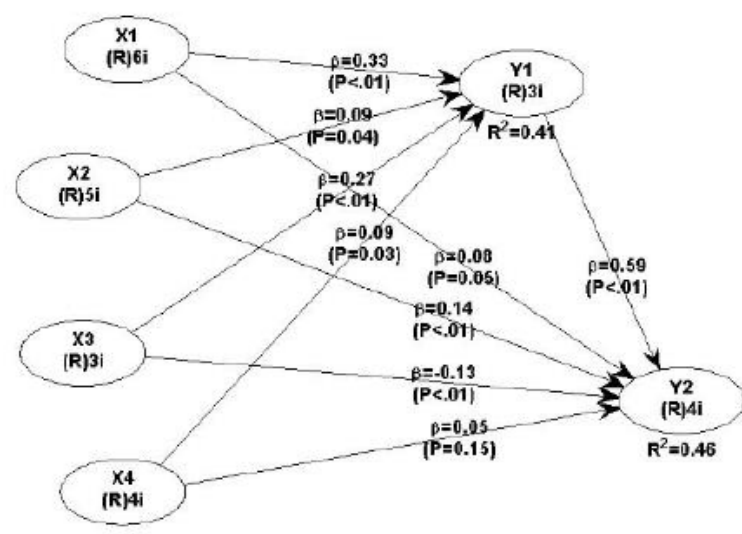

Figure 4 Research Model Using WarpPLS

The results of discriminant validity testing were obtained as follows:

Table 1 Nilai Discriminant Validity (Cross Loading)

\begin{tabular}{|c|c|c|c|c|c|c|}
\hline No & X1 & X2 & X3 & X4 & Y1 & Y2 \\
\hline X1.1 & 0.625 & 0.252 & -0.107 & -0.018 & -0.155 & 0.244 \\
\hline X1.2 & 0.652 & 0.082 & -0.016 & -0.153 & -0.006 & 0.156 \\
\hline X1.3 & 0.635 & -0.434 & 0.26 & 0.016 & -0.051 & 0.168 \\
\hline X1.4 & 0.710 & -0.253 & 0.001 & 0.236 & 0.127 & -0.411 \\
\hline X1.5 & 0.685 & 0.032 & -0.068 & 0.075 & -0.091 & -0.102 \\
\hline X1.6 & 0.629 & 0.431 & -0.097 & -0.229 & 0.226 & -0.029 \\
\hline X2.1 & 0.874 & 0.545 & -0.272 & 0.336 & 0.116 & 0.068 \\
\hline X2.2 & -0.04 & 0.693 & -0.116 & -0.005 & -0.169 & 0.016 \\
\hline X2.3 & -0.203 & 0.590 & 0.431 & 0.077 & 0.284 & -0.385 \\
\hline X.2.4 & -0.17 & 0.635 & -0.045 & -0.226 & -0.076 & 0.303 \\
\hline X2.5 & -0.09 & 0.647 & -0.007 & -0.015 & -0.008 & -0.041 \\
\hline $\mathrm{X} 3.1$ & 0.467 & -0.415 & 0.631 & 0.393 & 0.166 & -0.216 \\
\hline $\mathrm{X} 3.2$ & -0.396 & 0.192 & 0.723 & -0.203 & -0.063 & 0.314 \\
\hline $\mathrm{X} 3.3$ & -0.01 & 0.138 & 0.724 & -0.113 & -0.066 & -0.101 \\
\hline $\mathrm{X} 4.1$ & -0.016 & -0.089 & 0.079 & 0.841 & -0.174 & 0.127 \\
\hline $\mathrm{X} 4.2$ & -0.258 & 0.037 & 0.078 & 0.857 & 0.16 & -0.161 \\
\hline $\mathrm{X} 4.3$ & -0.062 & -0.052 & -0.02 & 0.887 & -0.036 & -0.026 \\
\hline $\mathrm{X} 4.4$ & 0.582 & 0.163 & -0.262 & 0.544 & 0.074 & 0.096 \\
\hline $\mathrm{Y} 1.1$ & -0.388 & 0.279 & 0.367 & -0.06 & 0.618 & -0.311 \\
\hline $\mathrm{Y} 1.2$ & 0.335 & -0.341 & -0.045 & -0.001 & 0.678 & 0.148 \\
\hline $\mathrm{Y} 1.3$ & 0.055 & 0.058 & -0.318 & 0.059 & 0.673 & 0.161 \\
\hline $\mathrm{Y} 2.1$ & 0.027 & -0.036 & 0.085 & -0.045 & 0.173 & 0.681 \\
\hline $\mathrm{Y} 2.2$ & -0.187 & 0.268 & 0.023 & -0.073 & -0.219 & 0.759 \\
\hline $\mathrm{Y} 2.3$ & -0.137 & 0.231 & -0.116 & -0.072 & 0.053 & 0.731 \\
\hline $\mathrm{Y} 2.4$ & 0.364 & -0.561 & 0.008 & 0.216 & 0.066 & 0.713 \\
\hline
\end{tabular}


The WarpPLS program is carried out using a T-test on each route. Hypothesis test parameters use a comparison of the $t$ value; that is, if the $\mathrm{p}$-value $(<0.05)$, then $\mathrm{H} 0$ is rejected, and $\mathrm{Ha}$ is accepted. The results of statistical analysis and testing can be seen in the table below:

Table 2 Result for Inner Weights

\begin{tabular}{|c|c|c|c|c|}
\hline No & Description & $\begin{array}{c}\text { Path } \\
\text { Coefficients }\end{array}$ & P-Value & $\begin{array}{c}\text { Value } \\
\text { Interpretation }\end{array}$ \\
\hline 1 & $\begin{array}{c}\text { Banking Service Quality (BSQ) (X1) } \\
\rightarrow \text { Satisfaction (Y1) }\end{array}$ & 0.331 & $<0.001$ & Positive Significant \\
\hline 2 & $\begin{array}{c}\text { Banking Service Quality (BSQ) (X1) } \\
\rightarrow \text { Loyalty (Y2) }\end{array}$ & 0.080 & 0.054 & $\begin{array}{c}\text { Positive Not } \\
\text { Significant }\end{array}$ \\
\hline 3 & $\begin{array}{c}\text { Shariah Compliance (X2) } \rightarrow \\
\text { Satisfaction (Y1) }\end{array}$ & 0.087 & 0.040 & Positive Significant \\
\hline 4 & $\begin{array}{c}\text { Shariah Compliance (X2) } \rightarrow \text { Loyalty } \\
(Y 2)\end{array}$ & 0.138 & 0.003 & Positive Significant \\
\hline 5 & $\begin{array}{c}\text { Switching Barriers (X3) } \rightarrow \text { Satisfaction } \\
(Y 1)\end{array}$ & 0.271 & $<0.001$ & Positive Significant \\
\hline 6 & $\begin{array}{c}\text { Switching Barriers (X3) } \rightarrow \text { Loyalty } \\
(Y 2)\end{array}$ & -0.130 & 0.004 & Negative \\
\hline 7 & $\begin{array}{c}\text { Religion Effect (X4) } \rightarrow \text { Satisfaction } \\
(Y 1)\end{array}$ & 0.092 & 0.032 & Positive Significant \\
\hline 9 & $\begin{array}{c}\text { Religion Effect (X4) } \rightarrow \text { Loyalty (Y2) } \\
\text { Satisfaction (Y1) } \rightarrow \text { Loyalty (Y2) }\end{array}$ & 0.051 & 0.154 & $\begin{array}{c}\text { Positive Not } \\
\text { Significant }\end{array}$ \\
\hline
\end{tabular}

Source: Data processing with WarpPLS, 2020

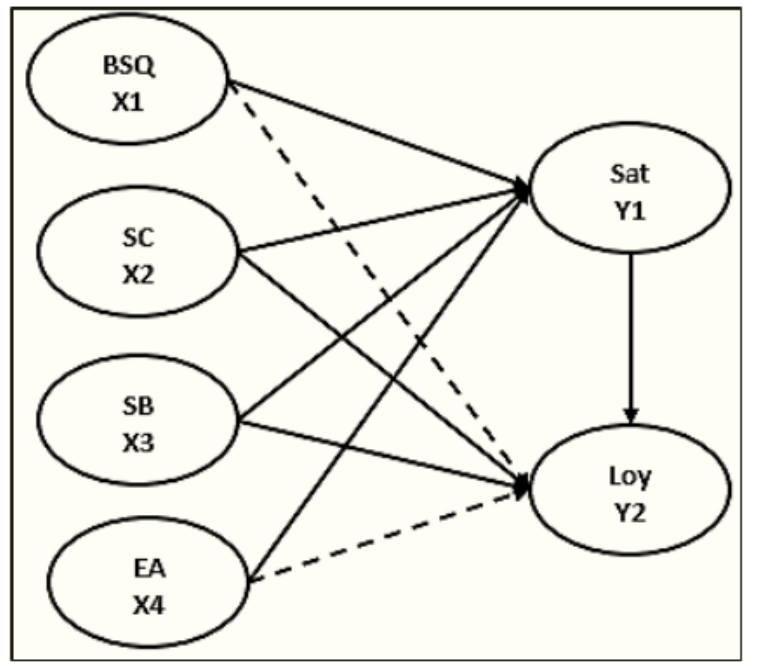

Figure 5 The influence between research variables 


\section{CONCLUSIONS AND SUGGESTIONS}

Banking Service Quality (BSQ), Shariah Compliance, Switching Barriers, Religious Effect has a significant positive effect on customer satisfaction for Islamic commercial banks in the province of East Kalimantan. This indicates that the higher the variable, the higher the level of customer satisfaction for Islamic commercial banks in East Kalimantan province. Effective means that the variables affect customer satisfaction or become very important.

Banking Service Quality (BSQ) and Religious Effect has a positive not significant effect on customer loyalty for Islamic commercial banks in the East Kalimantan province. Not significant means that the influence of customer loyalty variables is low or does not significantly affect customer loyalty at Islamic commercial banks in East Kalimantan province.

Shariah Compliance, Switching Barriers, Religious Effect, and satisfaction has a significant positive effect on customer loyalty for Islamic commercial banks in the province of East Kalimantan. This indicates that the higher the variable, the higher the level of customer satisfaction for Islamic commercial banks in East Kalimantan province. Effective means that the variables affect customer satisfaction or become very important.

Some suggestions that can be given about the results of this study are as follows:

- it is necessary to maintain the quality of banking services towards existing customer satisfaction and pay more attention to the level of banking service quality towards customer loyalty because the quality of banking services from the research results shows a positive and insignificant relationship with loyalty, so it is recommended that the management of Islamic commercial banks in east Kalimantan province increase customer loyalty in the quality of banking services.

- Should maintain and increase customer satisfaction and loyalty through sharia compliance so that while maintaining Shariah compliance as a unique characteristic of their Islamic banking, the level of customer satisfaction is higher with the fulfillment of sharia law in sharia commercial banks (bus). Likewise, the switching barriers variable still maintains the switching barriers variable or obstacles to moving to Islamic commercial banks in the province of East Kalimantan.

- It is necessary to maintain and increase the religiosity effect on existing customer satisfaction and pay more attention to the level of religiosity effect on customer loyalty because the religiosity effect of the research results shows a positive and insignificant relationship with loyalty, so it is recommended that the management of Islamic commercial banks in east Kalimantan province increase customer loyalty in the variable side of the religiosity effect. as well as satisfaction with customer loyalty, management should be maintained

\section{REFERENCES}

[1] Ahmed, D. J. U. (2010). Customers Orientation And Service Quality of Commercial Banks : The Empirical. 6502, 174-203.

[2] Alam, S. S., Mohd, R., \& Hisham, B. (2011). Is religiosity an important determinant on Muslim consumer behavior in Malaysia? Journal of Islamic Marketing, 2(1), 83-96. https://doi.org/10.1108/17590831111115268

[3] Amin, M., \& Isa, Z. (2008). An examination of the relationship between service quality perception and customer satisfaction: A SEM approach towards Malaysian Islamic banking. International Journal of Islamic and Middle Eastern Finance and Management, 1(3), 191-209. https://doi.org/10.1108/17538390810901131 
[4] Amin, M., Isa, Z., \& Fontaine, R. (2013). Islamic banks: Contrasting the drivers of customer satisfaction on image, trust, and loyalty of Muslim and non-Muslim customers in Malaysia. International Journal of Bank Marketing, 31(2), 79-97. https://doi.org/10.1108/02652321311298627

[5] Asnawi, N., Sukoco, B. M., \& Fanani, M. A. (2019). The role of service quality within Indonesian customers satisfaction and loyalty and its impact on Islamic banks. Journal of Islamic Marketing, 11(1), 192-212. https://doi.org/10.1108/JIMA-03-2017-0033

[6] Bahia, K., \& Nantel, J. (2000). A reliable and valid measurement scale for the perceived service quality of banks. International Journal of Bank Marketing, 18(2), 84-91. https://doi.org/10.1108/02652320010322994

[7] Berry, A. P. V. A. Z. L. L. (1988). SERVQUAL: A Multiple-Item Scale for Measuring Consumer Perceptions of Service Quality. Journal of Retailing Marketing Science Institute, Cambridge, MA.

[8] Bloemer, J., de Ruyter, ko, \& Peeters, P. (1998). Investigating drivers of bank loyalty: The complex relationship between image, service quality, and satisfaction. International Journal of Bank Marketing, 16(7), 276-286. https://doi.org/10.1108/02652329810245984

[9] Caruana, A. (2002). Service loyalty: The effects of service quality and the mediating role of customer satisfaction. European Journal of Marketing, 36(7/8), 811-828. https://doi.org/10.1108/03090560210430818

[10] G.P, S., Kamariah Nik Mat, N., O.I, A., A.S, M., \& ALekam, J. (2012). Customer Loyalty in eBanking: A Structural Equation Modelling (SEM) Approach. American Journal of Economics, 2(4), 55-59. https://doi.org/10.5923/j.economics.20120001.13

[11] Hazra, D. S. G., Piyush, P., \& Kumar, and T. (2013). CUSTOMER LOYALTY IN INDIAN BANKING SECTOR A. 6502, 236-243.

[12] Kau, A. K., \& Loh, E. W. Y. (2006). The effects of service recovery on consumer satisfaction: A comparison between complainants and non-complainants. Journal of Services Marketing, 20(2), 101-111. https://doi.org/10.1108/08876040610657039

[13] Kotler. (2015). Pengaruh Religiusitas, Motivasi Dan Persepsi Nilai Terhadap Loyalitas Nasabah Dalam Menggunakan Produk Bank Syariah. Pemasaran, Manajemen.

[14] Maswadeh, S. N. (2015). An Evaluation of SMEs Satisfaction Toward Jordanian Islamic Banks Service Quality. Procedia Economics and Finance, 23(October 2014), 86-94. https://doi.org/10.1016/s2212-5671(15)00463-3

[15] OJK, O. J. K. (2018). Sharia Banking Statistics, September 2018. 23. https://www.ojk.go.id/id/kanal/syariah/data-dan-statistik/statistik-perbankansyariah/Documents/Pages/Statistik-Perbankan-Syariah---September-2018/SPI September 2018.pdf

[16] Osman, Z., Mohamad, R. K., \& Mohamad, L. (2016). Mediating Effect of Customer Satisfaction on Service Quality and Trust Relationship in Malaysian Banking Industry. International Journal of Advances in Management, Economics, and Entrepreneurship, 3(1), 10-19.

[17] Othman, A., \& Owen, L. (2001). The multi dimensionality of carter model to measure customer service quality (S.Q.) in Islamic banking industry: a study in Kuwait finance house. International Journal of Islamic Financial Services, 3(4), 1-12. 
Determinants of Customer Satisfaction and Loyalty of Sharia Commercial Banks in Province East Kalimantan

[18] Shaikh, R., \& Siddiqui, D. A. (2018). Bank service quality on customer satisfaction, loyalty: a study based on Islamic banks in Pakistan. Study Based on Islamic Banks in Pakistan, 6(2), 830839. https://papers.ssrn.com/sol3/papers.cfm?abstract_id=3381554

[19] Shanka, M. S. (2012). Bank Service Quality, Customer Satisfaction and Loyalty in Ethiopian Banking Sector. Journal of Business Administration and Management Sciences Research, 1(1), 1-9. http://www.apexjournal.org/JBAMSR

[20] Sunaryo. (2013). Relatıonshıp Service Quality to Muslım Customer Loyalty in Islamıc Bankıng : Satısfaction as Mediator. Asia-Pacific Management and Business Application, 1, 72 83.

[21] Tabrani, M., Amin, M., \& Nizam, A. (2018). Trust, commitment, customer intimacy and customer loyalty in Islamic banking relationships. International Journal of Bank Marketing, 36(5), 823-848. https://doi.org/10.1108/IJBM-03-2017-0054

[22] Zeithaml, V. A., Bitner, M. J., \& Gremler, D. D. (2010). Services Marketing Strategy. Wiley International Encyclopedia of Marketing, December. https://doi.org/10.1002/9781444316568.wiem01055. 